check whether the definition of embryo contained in the act (as well as that of fertilization) can be interpreted sufficiently widely to convince the authority that it has the power to regulate any human applications of the Roslin work.

If not, admitted Deech, it will be necessary to go back to Parliament and to ask to have the wording of the act broadened - a move that runs the risk of giving legislators opposed to all research using human embryos an opportunity to seek support for an outright ban on any work relating to the cloning of human tissues.

Deech, reflecting the feeling of many scientists, is keen to maintain as much flexibility as possible. "[Parliament] may feel that the public mood requires a total prohibition on such work," she told the select committee. "But we feel strongly that, given that the Secretary of State [for Health] has powers under the act to prohibit certain types of work, public concerns can best be met by clarifying, and if necessary broadening, the definition of embryo."

DAVID DICKSON

\section{Japan considers ethics of genetic screening}

Japan has been been catapulted into an overdue debate on the ethical implications of genetic screening, by protests over a set of guidelines for the detection of hereditary diseases in artificially fertilized eggs. The guidelines were being considered by the Japan Society of Obstetrics and Gynecology when, at a recent executive board meeting, the room was stormed by a patients' advocacy group who demanded that the guidelines be shelved. The guidelines would have allowed couples who had requested prenatal testing of artificially fertilized eggs to ask for the eggs to be discarded if the analysis showed that a resulting child would be born with a genetic disease.

The society's ethics committee and senior directors had already approved the guidelines, and the board meeting was expected to adopt them. However, the society has now decided to conduct a more open discussion by consulting its 16,000 members and other academic societies before making a final decision. The protesters, from a patients' group opposed to eugenics, argue that discarding fertilized eggs with these diseases would be a form of discrimination against handicapped people. Kazunori Ochiai, a senior society doctor, counters that discarding eggs is not discrimination, but selection. It is the patients' right to have the test if they request it, he says, and the draft guidelines were designed as a procedure of informed choice to deal safely with these requests.

The society's move towards adopting guidelines had followed requests from researchers at Kagoshima University's medical school, in southern Japan, who wanted approval to conduct tests. Other doctors who have been asked by couples for genetic screening to be carried out had also sought advice from the society.

The decision to postpone adopting the guidelines has been welcomed by the Japanese press and government officials. They argue that a wide debate on the ethical implications of gene screening is necessary to form a consensus. The incident with the protesters has now forced that debate to start, says an official of the Ministry of Heath and Welfare. The ministry itself, meanwhile, is not currently considering setting up a committee to look into gene screening although the possibility that a ministry advisory committee may be formed in the future has not been ruled out. The prospect of a long debate worries researchers and supporters of the guidelines. They say they have witnessed years of inconclusive official discussion in Japan over the ethical implications of other biomedical developments, such as the recognition of "brain death" and the introduction of the low-dosage contraceptive pill (Nature Medicine 1, 1115; 1995).

Japan, which historically likes to treat its citizens equally, has been slow to come to grips with the practical and ethical implications of genetic screening, and whereas Japanese life insurance companies are not considering using genetic information in the assessment of insurance premiums, health policy researchers expect the gene screening debate to be protracted.

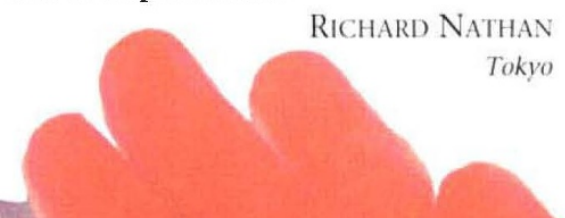

\title{
... and Britain considers impact on life insurance
}

British insurance companies have drawn mixed reviews for their joint decision to accept a two-year moratorium on the use of genetic information in assessing life insurance premiums for individuals seeking house mortgages of up to $£ 100,000$ (US\$160,000).

The proposed moratorium is the key element in a set of guidelines that has been drawn up by the Association of British Insurers in response to concerns expressed two years ago by the House of Commons select committee on science and technology (see Nature Medicine 1, $1109 ; 1995)$. In a broad-ranging report on human genetics, the committee threatened to seek legislation on the topic if the industry did not establish its own rules.

The industry's guidelines have been welcomed by Ian Taylor, the minister for science, who said during a parliamentary debate last month that he wanted to avoid any "misunderstandings" about the involvement of insurance companies in genetics. But critics point out that the industry is still demanding the right of access to genetic tests carried out on applicants for insurance.

While both welcoming the ABF's "con- cession" and applauding those companies which have already promised to go further by adopting broader restrictions on the use of genetic information, the select committee has expressed concern that "it has taken so long to produce such a limited reform." It points out that the industry has not even begun to consider the use of such information in nonmortgage related life insurance, and recommends that the newly constituted Human Genetics Advisory Committee should examine the ABI's proposals "as a matter of urgency."

DAVID DICKSON 